\title{
İşbirlikli Öğrenme Yönteminin Yüksekokul Öğrencilerinin Muhasebe Denetimi Konularını Anlamaları Üzerine Etkisi
}

\author{
Esra ATABAYa, , Gökhan DEMİRCİĞLUc
}

\section{Özet}

Bu çalışmanın amacı, işbirlikli öğrenme yönteminin yüksekokul öğrencilerinin muhasebe denetimi konularını anlamaları üzerine etkisinin belirlenmesidir. Çalışmada yarı-deneysel yöntem kullanılmıştır. Çalışma, Trabzon Üniversitesi Vakfıkebir Meslek Yüksekokulu "Muhasebe ve Vergi Uygulamaları" ile "Maliye" programlarında muhasebe denetimi dersi alan 91 öğrenci ile yürütülmüş̧ür. İlk programda öğrenim gören 48 öğrenci deney grubu ve sonraki programda öğrenim gören 43 öğrenci kontrol grubu olarak belirlenmiştir. Deney grubu öğrencileri işbirlikli öğretim yöntemi kullanılarak öğretilirken kontrol grubu öğrencileri geleneksel yaklaşımla (öğretmen merkezli) öğretilmiştir. Veri toplama araçları olarak, "Akademik Başarı Testi" ve "Jigsaw Görüş Ölçeği (JGÖ)" kullanılmıştır. Başarı testi her iki gruba ön ve son-test olarak iki kez uygulanırken, JGÖ sadece deney grubuna son-test olarak uygulanmıştır. Yapılan analizler sonucunda, geleneksel yöntemle karşılaştırıldığında işbirlikli öğrenme yönteminin yüksekokul öğrencilerinin muhasebe denetimi konularını anlamaları üzerinde istatistiksel olarak anlamlı bir fark oluşturmadığı belirlenmiştir.
Anahtar Kelimeler

İşbirlikli Öğrenme Yöntemi

Muhasebe Denetimi

Jigsaw Tekniği

Önlisans Denetim Eğitimi

Makale Hakkında

Geliş Tarihi: 13.07.2019

Kabul Tarihi: 13.03.2020

Doi: 10.18026/cbayarsos.591634

\section{The Effect of Cooperative Learning Method on The Understanding of Auditing Issues of College Students}

\begin{abstract}
The aim of this study is to determine the effect of cooperative learning method on the college students' understanding of auditing subjects. Semi-experimental method was used in the study. The study was carried out with 91 students who took auditing courses inDepartment of Accounting and Taxation and Department of Public Finance in Trabzon University Vakfıkebir Vocational School. 48 students from the first department were enrolled in the experimental group and 43 students were enrolled in the next department. While the experimental group students were taught using cooperative teaching method, the control group students were taught with a traditional approach (teacher centered). Academic Achievement Test "and" Jigsaw Opinion Scale (JOS) "were used as data collection tools. While the Achievement Test was applied to both groups as a pre- and post-test, the JOS was applied as a final test only to the experimental group. As a result of the analyzes, it was determined that the cooperative learning method did not make a statistically significant difference in terms of the college students' understanding of the auditing subjects compared to the traditional method.
\end{abstract}

Keywords

a İletişim Yazarı: eatabay@trabzon.edu.tr

b Dr. Öğr. Üyesi, Trabzon Üniversitesi, Vakfıkebir Meslek Yüksekokulu, Muhasebe ve Vergi Bölümü, 0000-0002-6855-7521.

c Prof. Dr. Trabzon Üniversitesi, Matematik ve Fen Bilimleri Eğitimi Bölümü, 0000-0002-5731-1761. 


\section{Giriş}

Ticaret meslek liseleri ile ön lisans ve lisans düzeyinde eğitim sunan yükseköğretim kurumları temel düzeyde muhasebe eğitimi vermektedir. Eski adıyla Ticaret Meslek Liseleri, yeni adıyla Mesleki ve Teknik Anadolu Liselerindeki öğrenciler 10. Sınıf itibariyle branşlaşmakta ve bu doğrultuda eğitim almaktadırlar. Söz konusu liselerde Muhasebe ve Finansman alanını seçen öğrencilere temel düzeyde muhasebe eğitimi hem teorik hem de son sınıf itibariyle haftada üç gün işyeri uygulaması şeklinde verilmektedir (Meslek Lisesi Staj Yönetmeliği, 5nci Kısım, 3ncü Bölüm, Md. 191). Meslek lisesi mezunu olmayan fakat muhasebe ile ilgili bir kariyer hedefleyen kişiler gerekli olan muhasebe eğitimini yükseköğretim kurumlarına devam ederek alabilmektedirler. Yükseköğretim düzeyinde muhasebe eğitimi ön lisans ve lisans programlarında verilmektedir. Ön lisans düzeyinde Muhasebe ve Vergi Bölümlerinde, lisans düzeyinde İktisadi ve İdari Bilimler Fakültesi işletme, iktisat, maliye, kamu yönetimi, çalışma ekonomisi vb. bölümler ile Açı Öğretim Fakültesinin İşletme ve İktisat fakültelerinde çeşitli muhasebe alan dersleri yer almaktadır. Ön lisans programlarında farklı eğitim modelleri olmakla birlikte genel olarak, dersler teorik ve eğitim-öğretim dönemleri haricinde (genellikle yaz aylarında) yapılması zorunlu olan,3060 işgünü arasında değişen staj şeklinde yürütülmektedir (Mesleki ve Teknik Eğitim Bölgesi İçindeki Meslek Yüksekokulu Öğrencilerinin İşyerlerindeki Eğitim, Uygulama ve Stajlarına İlişkin Esas ve Usuller Hakkında Yönetmelik, 2002, Madde:17). Lisans programlarında ise dersler sadece teorik olarak yürütülmekte, staj zorunluluğu bulunmamaktadır.

Her meslekte olduğu gibi, muhasebecilik mesleğinin de icra edilebilmesi için teorik eğitimin işyeri uygulama eğitimiyle desteklenmesi gerekir. Ön lisans programlarındaki zorunlu staj uygulamasının verimi öğrenci, işletme, öğretim elemanı veya yasal mevzuat kaynaklı birçok sorun nedeniyle azalmaktadır. Öğrenciye uygun işletmenin bulunamaması (Erol, 2004:139), staj yapılan işletmede işlerin yoğun olması, stajyere geçici eleman gözüyle bakılması, stajyerin bir yük olarak görülmesi ve önemsenmemesi (Karacan ve Karacan, 2004:178), mesleki gelişimlerini arttıracak işlerin yaptırılmaması (Demir, 2015:79), öğretim elemanlarının öğrencileri yerinde ve zamanında denetleme imkânlarının olmaması ve teori ile uygulama bütünlüğünün tam olarak sağlanamaması (Erol, 2004:140,142) gibi faktörler staj uygulamasından beklenen amacı karşılamamaktadır. Bu nedenle muhasebe eğitiminde öğrencinin olabildiğince derse aktif katılımı sağlanarak uygulamaya yönelik eksikliğin giderilmesi ve muhasebe derslerinin zor ve sıkıcı olduğu yönündeki algının azaltılması gerekir. Öğrencinin aşina olmadığı aktif katılımlı dersler, başlangıçta öğrenciye zor gelse de, zamanla kendi isteğiyle derslerine hazırlıklı gelmesine ve öğrenmesinin sorumluluğunu almasına katkı sağlamaktadır.

Geleneksel öğretim anlayışında sıklıkla, öğretmen daha önceden kurguladığ ${ }_{1}$ bilgileri belirli bir mantık sırasında sözel olarak öğrencilere sunmakta ve öğrenciler ise sunulan bu bilgileri dinleyip not alarak öğrenmeye çalışmaktadır. Öğrenci merkezli öğretimde ise, öğrenci pasif konumdan çıkıp hem bedensel hem de zihinsel olarak sürece dâhil olduğu aktif bir konuma geçmektedir. Bu anlayışta öğrenci, kaynaklara kendisi ulaşmakta, bilgiye ulaşmanın yollarını öğrenmekte, elde ettiği bilgileri zihninde yapılandırmaya çalışmakta, öğrenmesinin sorumluluğunu almakta, arkadaşlarıyla etkileşimde bulunmakta ve ortak öğrenme amacına yönelik akranlarıyla işbirliği içerisinde çalışmaktadır. Öğretmen merkezli öğretimden öğrenci merkezli öğretime geçişte birçok öğretimsel model, yöntem, teknik ve materyal geliştirilmiş ve geliştirilmeye devam etmektedir. 90'lı yılların sonundan itibaren ülkemizde 
de eğitimin kalitesini arttırmaya yönelik, özellikle çağdaş öğretim yöntem ve teknikleri üzerine, çok sayıda bilimsel çalışma yapılmış (Demircioğlu, Vural ve Demircioğlu, 2012; Özkıdık, 2010; Yıldırım, 2011)ve çalışmaların birçoğunun sonuçları eğitim sistemimize entegre edilmeye çalışılmaktadır. Bununla birlikte ülke olarak bu entegrasyon sürecinde çok yol aldığımızı söylemek iyimserlik olur. Okullarımızda halen daha yaygın bir şekilde öğretmen merkezli öğretim uygulamaları gözlenmektedir.

Yukarıda bahsi geçen çağdaş öğretim yöntemlerinden biri de öğrencinin akademik başarısını arttırmanın yanında farklı beceriler de kazandırmayı amaçlayan işbirlikli öğrenme yöntemidir. İşbirlikli öğrenme kısaca öğrencilerin birbirlerinin öğrenmelerine yardım edecek şekilde küçük gruplar halinde çalıştıkları öğrenme yöntemi ya da modeli olarak tanımlanmaktadır (Slavin, 2008). Bu yöntem, ayrıca öğrencilerin sorumluluk alma becerilerini arttırmakta, sosyal becerilerini geliştirmekte ve ortak bir amaca yönelik bir arada çalışma beceri ve algılarını arttırmaktadır (Slavin, 1980).Genel olarak bakıldığında işbirlikli öğrenme öğretmenden ziyade öğrenci merkezli olup süreçte öğrenci aktiftir (Cooper and Mueck,1990).Sınıf içerisinde doğru ve planlı uygulandığında, işbirlikli öğrenme yönteminin geleneksel yaklaşıma nazaran öğrenci başarısını arttırdığı birçok farklı alandaki çalışmada belirtilmektedir (Tezcan, Yilmaz ve Babaoğlu, 2005; Anderson, Mitchell ve Osgood, 2005; Kartal ve Özbek, 2017; Genç, 2007; İstemil, 2011; Nichols\& Miller, 1994; Özkıdık, 2010;Özsarı, 2009; Slavin, 1990).Aydın ve Er (2011), Cottell ve Millis (1992), Hwang ve arkadaşları (2005) tarafından yapılan çalışmalarda işbirlikli öğrenme yöntemi ile öğrencilerin akademik performansları ve muhasebe algıları arasında olumlu bir ilişki olduğu tespit edilmiştir. Ayrıca Hwang ve arkadaşları (2005) muhasebe öğretiminde öğrencinin pasif olduğu öğrenme yöntemleri yerine işbirlikli aktif öğrenme yöntemlerinin kullanılması gerektiğini ifade etmektedirler. Aydın ve Er (2011), lisans düzeyinde Genel muhasebe dersine devam eden 75 öğrenci (45'i deney, 30'u kontrol grubu) üzerinde yaptığı çalışmada işbirlikli öğrenme yönteminin genel muhasebe kavram ve ilkelerini öğrenme sürecine etkin olarak katkısı olduğunu belirtmişlerdir. Hwang ve arkadaşları (2005),muhasebe dersi kapsamında yer alan ve finansal raporlama için temel olarak kabul ettikleri Hisse Başına Kazanç konusunu anlama ve kavrama bakımından işbirlikli öğrenme yöntemini uygulamışlar ve yöntemin geleneksel yönteme kıyasla daha verimli olduğu sonucuna ulaşmışlardır. Muhasebe alan dersleri dikkate alınarak yapılan ve bu sonucun aksi yönde sonuç bildiren çalışmalar da mevcuttur. Caldwell ve arkadaşları (1996),580 öğrenci (289'u deney, 291'i kontrol grubu) üzerinde yaptıkları çalışmada, başlangıç düzeyindeki muhasebe öğrencilerinin muhasebe algıları üzerinde işbirlikli öğrenme yönteminin etkisini incelemişlerdir. Çalışma sonucunda "Muhasebe İlkeleri I" dersi için işbirlikli öğrenme yönteminin etkili olduğunu, fakat "Muhasebe ilkeleri II" dersi için etkili olmadığını belirlemişlerdir. Birinci dönem dersi olan Muhasebe İlkeleri I dersinde yöntemin etkili olmasını, öğrencilerin muhasebe derslerine karşı başlangıçta pozitif bir bakış açısına sahip olmalarına fakat ders ilerledikçe bu pozitif bakış açısının azalmasına bağlamışlardır. Kunkel ve Shafer (1997), 63'üne işbirlikli öğrenme, 66'sına geleneksel yöntem uyguladığ toplam 129 üniversite son sınıf öğrencisinin aldığı muhasebe denetimi dersi üzerinde işbirlikli öğrenme yönteminin etkisini araştırmışlar ve yöntemin başarı üzerinde etkili olmadığı sonucuna ulaşmışlardır. Daha önce yapılan çalışmaların aksi yönde bir sonuç elde etmelerinin iki nedeni olabileceğini öne sürmüşlerdir. İleri sürdükleri birinci neden, daha önceki çalışmaların ilk, orta ve üniversitelerin başlangıç düzeyindeki sınıflarda okuyan öğrenciler üzerinde yapılmış olmasıdır. Kendi çalışmalarının ise son sınıf öğrencileri üzerinde 
olmasıdır. Son sınıf öğrencileri, takım halinde çalışmadan ziyade kendi kendilerine çalışma ve öğrenmeyi alışkanlık haline getirmişlerdir. Bu nedenle, araştırma sonucunda, işbirlikli öğrenme yönteminin etkili olmadığını ileri sürmektedirler. Yöntemin etkili olmamasının ikinci nedeni olarak, takım halinde çalışan gruplara, takım performansları karşılığı ödül puan verilmesini göstermişlerdir. Çalışmada işbirlikli gruplar, ödül puan alacaklarını bildiklerinden dolayı rahat davranmışlar ve bunun sonucunda sinavlardan daha düşük notlar almışlardır. Riley ve Ward (2017), muhasebe bilgi sistemleri alanında pasif öğrenme yöntemine karşı aktif öğrenmenin etkililiğini incelemişlerdir. İki grup aktif öğrenme koşulları altında (bireysel aktif öğrenme ve işbirlikli aktif öğrenme) derslere katılırken üçüncü grup pasif öğrenmeye tabi tutulmuştur. Pasif öğrencilerle aktif öğrenciler kıyaslandığında, aktif gruplar içinde, özellikle bireysel olarak çalışan öğrencilerin sinav performanslarında anlamlı farklılıklar tespit edilmiştir. İşbirlikli öğrenme yönteminin uygulandığı öğrencilerin sınav notlarında ise pasif öğrencilere nazaran anlamlı bir farklılık bulunmamıştır. Lancaster ve Strand(2001), lisans düzeyindeki yönetim muhasebesi dersinde işbirlikli öğrenme yönteminin öğrenci algısı ve akademik performans üzerindeki etkisini araştırmışlardır. Çalışma sonucunda gruplar arasında anlamlı farklılık olmadığ belirlenmiştir.

\section{Amaç}

$\mathrm{Bu}$ çalışmanın amacı, ön lisans düzeyindeki muhasebe öğrencilerinin muhasebe denetimi dersindeki akademik başarıları üzerinde işbirlikli öğrenme yönteminin etkili olup olmadığına dair bir sonuç ortaya koymaktır. Bu doğrultuda, ön lisans düzeyinde "Muhasebe Denetimi" alan öğrencilerin akademik başarıları üzerinde işbirlikli öğrenme yöntemi ile geleneksel öğrenme yönteminin etkisi araştırılmıştır. Akademik başarı üzerinde söz konusu iki yöntemden hangisinin daha etkili olduğunu tespit etmek amaciyla, uygulamadan önce ve sonra çalışma gruplarının akademik başarı düzeyleri karşılaştırılmış ve aralarında bir farklılık olup olmadığı test edilmiştir.

\section{Araştırma Modeli}

\section{Yöntem}

Bu çalışmada, yarı-deneysel yöntem kullanılmıştır. Bu yöntem, deney ve kontrol gruplarının oluşturulmasının yansız atama ile yapılamadığı durumlarda, özellikle eğitim araştırmalarında, sıklıkla kullanılmaktadır (Judd, Smith ve Kidder, 1991). Mevzuat gereği okullarda mevcut sinıfların yeniden oluşturulmasına izin verilmemektedir. Bu nedenle yansız atama ile sınıfların (grupların) oluşturulması oldukça zordur, hatta imkânsızdır. Bu çalışmada muhasebe denetimi dersini alan iki sınıftan biri deney, diğeri ise kontrol grubu olarak rastgele bir şekilde belirlenmiştir. Yöntemin farklı uygulama desenleri olmakla birlikte geçerliği ve güvenirliği daha yüksek olan "ön-test/son-test kontrol gruplu desen" bu çalışmada tercih edilmiştir (Robson, 1998). Bu desende gruplar, yansız atama dışında bir yöntemle oluşturulmakta ve deney öncesi ve sonrası olmak üzere iki kez teste tabi tutulmaktadir.

$\mathrm{Bu}$ çalışmada grup karşılaştırmaları için, deney ve kontrol grubu öğrencilerine uygulama öncesi ve sonrasında "Akademik Başarı Testi" uygulanmıştır. Deney grubundaki öğretim etkinliklerinde İşbirlikli Öğrenme Yöntemi “Jigsaw Tekniği” kullanılırken, kontrol grubunda öğretmen merkezli geleneksel yaklaşım benimsenmiştir. Çalışmanın araştırma deseni, Tablo 1 'de gösterilmiştir. 
Tablo 1. Araştırmanın Deneysel Deseni

\begin{tabular}{lllll}
\hline Gruplar & Ön-test & Öğretim Yöntemi & Son-testler \\
\hline Deney Grubu & Akademik Başarı Testi & $\begin{array}{l}\text { İşbirlikli } \\
\text { Yöntemi }\end{array}$ & Öğrenme & Akademik Başarı Testi, \\
& & Jekniği & & \\
& & Jigsaw & Jigsaw Görüş Ölçeği \\
Kontrol Grubu & Akademik Başarı Testi & $\begin{array}{l}\text { Öğretmen } \\
\text { Geleneksel Yaklaşım }\end{array}$ & \\
& & Merkezli & Akademik Başarı Testi \\
\hline
\end{tabular}

\section{Çalışma Grubu}

Çalışma grubu, 2017-2018 eğitim öğretim dönemi Bahar yarıyılında Trabzon Üniversitesi Vakfıkebir Meslek Yüksekokulu Muhasebe ve Vergi Uygulamaları Programı ile Maliye Programında kayıtlı, "Muhasebe Denetimi" dersi alan toplam 91 öğrenciden oluşmaktadır. Muhasebe ve Vergi Uygulamaları programındaki 48 öğrenci (19 erkek, 29 kız) işbirlikli öğrenme modelinin uygulandığı deney grubu olarak belirlenirken Maliye Programında kayıtlı 43 öğrenci (15 erkek, 28 kız) öğretmen merkezli geleneksel yöntemin uygulandığ 1 kontrol grubu olarak belirlenmiştir.

\section{Veri Toplama Aract}

Bu çalışmada, ölçme araçları olarak; açık uçlu sorulardan oluşan "Akademik Başarı Testi" ile “Jigsaw Görüş Ölçeği (JGÖ)” kullanılmıştır.

Çalışmada, öğrencilerin akademik başarılarını ölçmek amacıyla araştırmacı tarafından "Muhasebe Denetimi" konularından "Finansal Tabloların Denetlenme Gereklilikleri", "Denetim Türleri ve Denetime Tabi Kuruluşlar", "Denetçiler", "Denetim Standartları", "Denetim İlkeleri", "Denetimin Başlangıcı", "Analitik İnceleme Teknikleri" ve "Denetimin Planlanması" olmak üzere 8 konunun kazanımlarını içeren 9 açık uçlu sorudan oluşan Akademik Başarı Testi (ABT) hazırlanmıştır. Sorular, öğrencinin bilgiyi hatırlayıp cevap vereceği türden ziyade akıl yürüterek ve yorum yeteneğini kullanarak cevap verilecek şekilde hazırlanmıştır. Soruların geçerliğinin belirlenmesinde muhasebe alanından 2 uzman ve eğitim alanından 1 uzman olmak üzere toplam üç uzmanın görüşlerinden yararlanılmıştır. Testin güvenirliği için puanlayıcılar arası güvenirlik (inter-raterreliability) yönteminden faydalanılmıştır. İki uzman birbirinden bağımsız şekilde öğrencilerin sınav kâğıtlarını (ABT) puanlamışlardır. Daha sonra iki uzmanın puanlama sonuçları, Pearson Momentler Çarpımı Korelasyon Katsayısı ve Ortalamaların Karşılaştırılması (t testi veya varyans analizi) teknikleri kullanılarak değerlendirilmiştir (Yelboğa, 2008:38).Bu hesaplamalar için SPSS 23 İstatistik Paket programı kullanılmıştır. Pearson Korelasyon Katsayısına ilişkin elde edilen bulgular Tablo 2'de gösterilmiştir. 
Tablo 2.Puanlayıcılar Arası Güvenirliğe İlişkin Pearson Korelasyon Katsayıları

\begin{tabular}{ll}
\hline Madde & Puanlayıcilar Arası Korelasyon \\
\hline 1 & $0,84^{* *}$ \\
2 & $0,91^{* *}$ \\
3 & $0,76^{* *}$ \\
4 & $0,54^{*}$ \\
5 & $0,85^{* *}$ \\
6 & $0,71^{* *}$ \\
7 & $0,85^{* *}$ \\
8 & $0,96^{* *}$ \\
9 & $0,86^{* *}$ \\
Toplam & $0,88^{* *}$
\end{tabular}

${ }^{* *} \mathrm{p}<0,01$

$* \mathrm{p}<0,05$

Tablo 2 incelendiğinde, iki puanlayıcının puanları arasındaki en yüksek korelasyon değerinin 0,96 ile 8. maddeye, en düşük korelasyon değerinin ise 0,54 ile 4.maddeye ait olduğu görülmektedir. Korelasyon değerleri, 0,30'dan küçük ise ilişkinin düşük, 0,30 ila 0,70 arasında ise orta ve 0,70'den büyük iseyüksek olduğu kabul edilir (Büyüköztürk, 2004). Buna göre 4. madde haricindeki tüm maddelerde puanlayıcılar arası korelasyon yüksek ve 0,01 düzeyinde anlamlı, 4. maddede ise orta düzeyde ve 0,05 düzeyinde anlamlı bulunmuştur. Puanlayıcıların maddelere verdikleri puanların ortalamaları arasındaki ilişkiye bakıldığında ise 0,88 ile yüksek bir korelasyon değeri gözlenmektedir.

Pearson Korelasyon Katsayısı kullanılarak belirlenen puanlayıcılar arası güvenirlik, "Ortalamaların Karşılaştırılması Yaklaşımı" ile tekrar hesaplanmış ve birlikte değerlendirilmiştir. Bu yaklaşımda, iki puanlayıcının her bir soruya verdiği puanların ortalamaları arasında istatistiksel olarak anlamlı fark olup olmadığı analiz edilir. Bağımsız örneklem t-testi ile yapılan analiz sonucu elde edilen bulgular Tablo 3'te gösterilmiştir.

Tablo 3.Puanlayıcıların Ortalama Puanlarının Karşılaştırılması

\begin{tabular}{llllll}
\hline Madde & 1.Puanlayıcının & 2.Puanlayıcının & Mutlak & t değeri & $\mathbf{p}$ \\
& Ortalaması & Ortalaması & Fark & & \\
\hline 1 & 2,50 & 2,10 & 0,40 & 0,902 & 0,373 \\
2 & 2,9 & 2,80 & 0,10 & 0,473 & 0,639 \\
3 & 1,65 & 1,35 & 0,30 & 1,217 & 0,231 \\
4 & 2,20 & 2,05 & 0,15 & 0,686 & 0,497
\end{tabular}




$\begin{array}{llllll}5 & 1,10 & 1,05 & 0,05 & 0,143 & 0,887 \\ 6 & 2,10 & 1,80 & 0,30 & 0,541 & 0,592 \\ 7 & 2,35 & 1,40 & 0,95 & 2,750 & 0,009^{*} \\ 8 & 1,10 & 0,65 & 0,45 & 1,288 & 0,205 \\ 9 & 0,50 & 0,45 & 0,05 & 0,230 & 0,819 \\ \text { Toplam } & 16,40 & 13,65 & 2,75 & 1,774 & 0,084\end{array}$

${ }^{*} \mathrm{p}<0,05$

Tablo 3, puanlayıcılar arasındaki güvenirliği göstermektedir. İki puanlayıcının yaptığı puanlamaların ortalamaları gerek madde bazında gerekse genel toplam açısından karşılaştırılmıştır. 7. maddeye ilişkin ortalamalar arasında istatistiksel olarak anlamlı farklılık tespit edilmiştir, $\mathrm{t}(38)=2,750, \mathrm{p}<0,05$. Fakat Tablo 2'ye bakıldığında 7.maddeye verilen puanlar arasındaki korelasyon katsayısı 0,85 ile yüksek düzeyde bulunmuştur. Toplam puana göre bakıldığında ise birinci değerlendiricinin puanı ikinci değerlendiriciye göre 2,75 puan daha yüksek çıkmıştır ancak bu değer istatistiksel olarak anlamlı değildir $t(38)=1.774$, $\mathrm{p}>0,05$. Bu sonuç, Tablo 2 'de belirlenen toplam puanlar arasındaki korelasyon değerinin $(0,88)$ yüksek bir ilişki göstermesi ile de desteklenmektedir.

\section{Jigsaw Görüş Ölçeği (JGÖ)}

Jigsaw Görüş Ölçeği (JGÖ), tekniğin uygulandığı deney grubu öğrencilerinin, yöntem ile ilgili görüşlerini belirlemek amacıyla kullanılmıştır. Şimşek (2007) tarafından geliştirilen ölçek, 5'li Likert tipinde 14 soru ve 1 tane açık uçlu soru olmak üzere toplam 15 sorudan oluşmaktadır. Öğrencilerden ifadelere, "çok fazla etkili", "biraz fazla etkili", "eşit etkili", "az etkili" ve "çok daha az etkili" şeklinde cevap vermeleri istenmiştir. Ayrıca, öğrencilerden, bu teknik ile ilgili belirtmek istedikleri olumlu veya olumsuz başka görüşlerinin olup olmadığını açık uçlu soru ile cevaplandırmaları istenmiştir.

\section{Uygulama}

Muhasebe denetimi dersi, hem deney hem de kontrol grubunda haftada 3 ders saati (3x50=150dk) olup, araştırma altı haftalık süreyi kapsamaktadır. İlk hafta ön-testler uygulanmış ve deney grubu öğrencilerine işbirlikli öğrenme yönteminin Jigsaw tekniği ve sürecin nasıl yürütüleceği hakkında bilgi verilmiştir. Bu işlem uygulama başlamadan önceki hafta yapılmıştır. Daha sonra öğretimi yapılacak konu ve kavramlar, beş alt başlık altında toplanmıştır. Buradan anlaşılacağı gibi 5 farklı Jigsaw etkinliği planlanmıştır. Bu ana konu başlıklarının her biri, 6 alt başlığa ayrılmıştır. Her hafta hangi konunun ve alt konularının ele alındığ 1 Tablo 4 'te verilmiştir.

Tablo 4. Deney grubunda yapılan etkinlik konularının dağılımı

\begin{tabular}{llll}
\hline Hafta & Ana Konu & & Alt Konular \\
\hline 1. hafta & Finansal Tabloların & Denetlenme & Finansal tabloların denetlenmesindeki \\
3 ders saati (150 & Gereklilikleri, Denetim Türleri ve & amaç ve gereklilik \\
& Denetime Tabi Kuruluşlar, Denetçiler & Bağımsız denetim ve kamu denetimi \\
& & Iç denetim \\
& & Bağımsız denetçiler \\
& & Denetime tabi kuruluşlar \\
\hline
\end{tabular}




\section{Hafta}

3 ders saati (150

$\mathrm{dk})$

3. Hafta

3 ders saati (150

$\mathrm{dk}$ )

4. Hafta

3 ders saati (150

$\mathrm{dk})$

5. Hafta

3 ders saati (150

$\mathrm{dk})$
Denetimin planlanması

Denetimin başlangıç aşaması ve analitik inceleme teknikleri

Denetimin planlanması

Denetim Standartları ve Denetim
İlkeleri

Bağımsız denetim kuruluşları

Genel kabul görmüş denetim

standartları

Uluslararası denetim standartları ve

Türkiye Denetim Standartları

Bağımsızlık ve objektiflik ilkesi

Mesleki özen ve titizlik ilkesi, mesleki etik ilkesi, yeterlilik ve muhakeme yeteneği ilkesi, net ve etkili raporlama ilkesi

Ticaret ve mesleğe aykırı faaliyet yasağı ilkesi, reklam yasağı ilkesi, sır saklama yükümlülüğü ilkesi, karşılıklı ilişkiler ve haksiz rekabet ilkesi

Konunun şematik olarak gösterimi

Denetim kuruluşunun seçimi

Müşteri işletme hakkında bilgi

toplanması

Denetim sözleşmesi

Sözleşme sonrası denetim faaliyetleri

Analitik incelemenin amaçları

Analitik inceleme teknikleri

Denetim planı ve yapılma amaçları

Genel denetim programı

Özet denetim programı

Denetim programının hazırlanması

Denetim planının hazırlanmasındaki

aşamalar

Önemliliğin planlanması

Denetim riskinin bileşenleri

Yapisal riskin ve kontrol riskinin

planlanması

Bulgu riskinin planlanması

Denetim riskleri arasındaki ilişkiler

Denetim süresinin planlanması

Denetim ekibinin planlanması

Konular ve alt konular belirlendikten sonra,48 öğrenciden oluşan deney grubu öğrencileri, genel akademik başarı ortalamaları dikkate alınarak heterojen şekilde 6'şarlı 8 gruba ayrılmıştır. Grupların temsili gösterimi Şekil 1'de verilmiştir. 


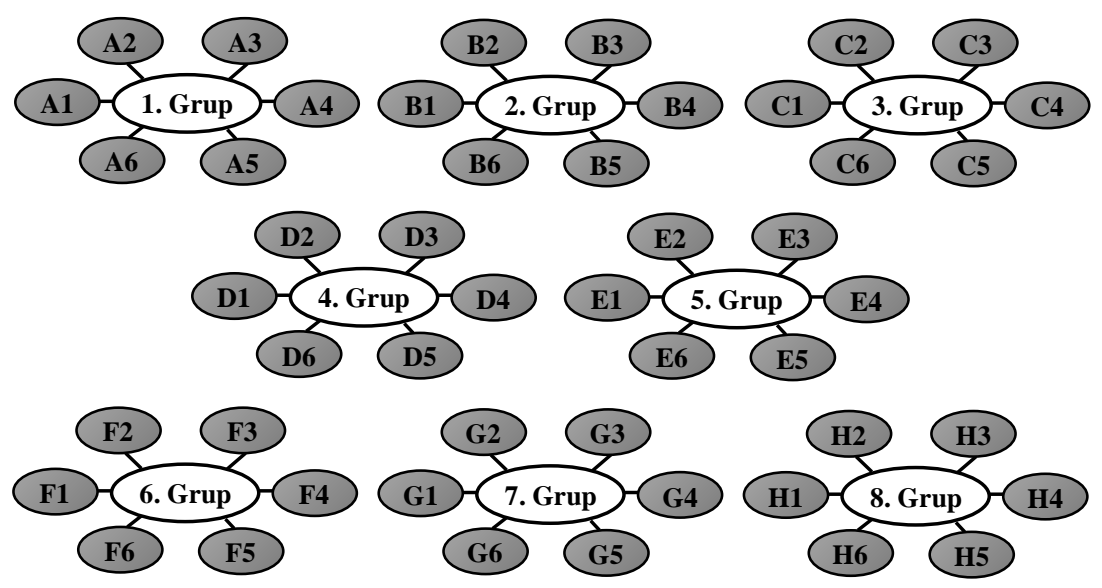

Şekil 1. İşbirlikli Öğrenci Grupları

Her grupta, akademik ortalaması en yüksek olan öğrenci, grup lideri olarak seçilmiştir. Araştırma kapsamındaki konular, haftalık olarak araştırmacı tarafından grup üyelerine dağıtılmıştır. Örneğin; birinci haftanın konusu olan "Finansal Tabloların Denetlenme Gerekliliği" ünitesi araştırmacı tarafından 6 alt başlığa bölünmüştür. Birinci alt başlık (finansal tabloların denetlenme gereği) A1, B1, C1, D1, E1, F1, G1, H1kodlu, ikinci alt başlık (bağımsız denetim kuruluşları) A2, B2, C2, D2, E2, F2, G2, H2kodlu, üçüncü alt başlık (iç denetim) A3, B3, C3, D3, E3, F3, G3, H3 kodlu, dördüncü alt başlık (bağımsız denetçiler)A4, B4, C4, D4, E4, F4, G4, H4 kodlu, beşinci alt başlık (bağımsız denetim ve kamu denetimi) A5, B5, C5, D5, E5, F5, G5, H5 kodlu ve altıncı alt başlık (denetime tabi kuruluşlar) A6, B6, C6, D6, E6, F6, G6, H6 kodlu kişilere çalışma konusu olarak verilmiş ve yaklaşık 40 dakika bu konuyu farklı kaynaklardan araştırmaları istenmiştir. Öğrencilerin ihtiyaç duyabileceği tüm kaynaklar (internet, çeşitli kaynak kitaplar) ortama getirilmiştir. Bu işlem tamamlandıktan sonra uzman gruplar oluşturulmuştur. Bu süreçte aynı konuyu çalışan bireyler bir grupta toplanmıştır. Oluşturulan uzman grupların temsili gösterimi Şekil 2' de verilmiştir.

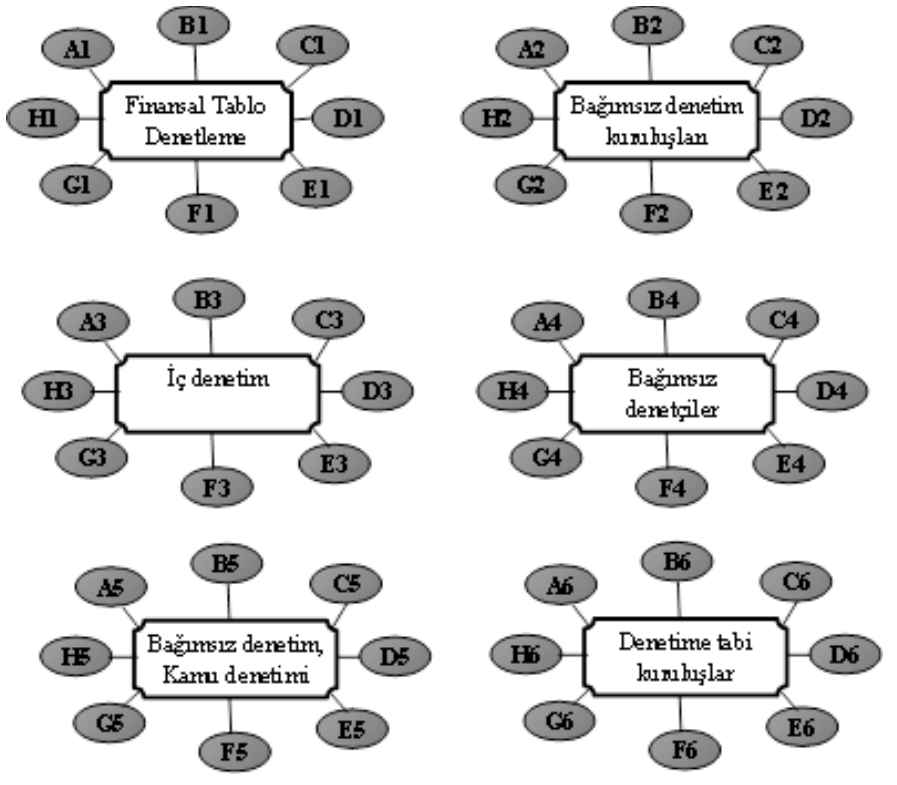

Şekil 2. İşbirlikli Uzman Gruplar 
Her haftanın konusu, araştırmacı tarafından ana grup liderlerine bir hafta önceden sözlü olarak bildirilmiş ve liderlerden Şekil 2' de verildiği gibi grubundaki üyelere alt başlıkları paylaştırması istenmiştir. Hem deney hem de kontrol grubu için 3 saatlik muhasebe denetimi dersi haftanın iki gününe bölünmüş ve grupların dersleri aynı gün olacak şekilde programlanmıştır. Haftanın ilk dersinde konusuna hazırlanmış olarak gelen öğrenciler uzman gruplarda bir araya gelerek bilgilerini ve öğrendiklerini birbirleriyle paylaşmışlardır. Uzman grupların konularını daha iyi kavramaları için öğretmen tarafından gruplara derinlemesine sorular sorulmuş ve bu soruların cevapları istenmiştir. Uzman gruplar haftanın ikinci ders oturumunda (2 ders saati)ana gruplarına dönmüşler ve her öğrenci uzmanlaştığı konuyu diğer arkadaşlarına öğretmeye çalışmıştır. Bu işlem tamamlandıktan sonra öğretmen o haftanın konularını özetlemiştir. Anlaşılmayan noktalara vurgu yapmıştır. Öğrencilerin varsa sorularına cevap vermiştir. Dersin son 15 dakikasında tüm öğrencilere yönelik üç açık uçlu sorudan oluşan bir quiz uygulanmıştır. Quiz sonuçları sonraki hafta ilk derste öğrencilere duyurulmuş ve birinci olan gruba ödül (final sınavı için ek 5 puan) verilmiştir. Diğer haftalardaki uygulamalar da benzer şekilde gerçekleştirilmiştir. Bu şekilde 5 hafta boyunca uygulama devam etmiştir.

Kontrol grubuna herhangi bir müdahalede bulunulmamıştır. Haftalık konular araştırmacı tarafından ders kitabında yer aldığı şekliyle, geleneksel anlatım ve soru-cevap teknikleri kullanılarak anlatılmıştır. Her ders başında bir önceki dersin konusu tekrarı edilmiş ve önemli yerler vurgulanmıştır.

Her iki grubun başlangıç başarı düzeylerinin belirlenmesi amacıyla, gruplara, uygulama öncesinde yöneltilen Akademik Başarı Testi (ABT) 5 haftalık uygulama sonrasında son-test olarak tekrar uygulanmıştır. Ayrıca, uygulama bittikten sonra sadece deney grubu öğrencilerine Jigsaw Görüş Ölçeği (JGÖ) uygulanmış ve bu gruptaki öğrencilerin teknik hakkındaki görüşleri tespit edilmiştir.

\section{Verilerin Analizi}

Başarı testinden elde edilen cevaplar, 5 kategori (cevapsı//boş, yanlış, kısmen doğru, yarı doğru ve tam doğru) altında toplanmıştır. Cevapsız/boş 0, yanlış 1, kısmen doğru 2, yarı doğru 3 ve tam doğru 4 puan ile puanlanmıştır. Grupların ön-test puanları, bağımsız örneklem t-testi ile değerlendirilirken son-test puanları Kovaryans (ANCOVA) analizine tabi tutulmuştur. Bunun nedeni öğrencilerin ön-test puanları arasında kontrol grubu lehine anlamlı bir fark oluşmasıdır. Bu durumda öğrencilerin ön-test verilerini eşitleyen Kovaryans analizi tercih edilmiştir. Jigsaw Görüş Ölçeğinden elde edilen verilerin, tanımlayıcı istatistikleri, frekans ve yüzde dağılımları hesaplanarak tablo halinde sunulmuştur.

\section{Bulgular}

Araştırmanın bu bölümünde, ABT ön-testi,ABT son-testi ve Jigsaw Görüş Ölçeğinin uygulanması ile elde edilen verilerin analiz sonuçları sunulmuştur.

\section{ABT'nin Ön-test Uygulamasindan Elde Edilen Bulgular}

ABT, çalışmaya katılan öğrencilerin çalışılan kavramlarla ilgili önbilgi düzeylerini belirlemek amacıyla uygulama öncesinde her iki gruba ön-test olarak uygulanmıştır. Bu testin diğer bir amacı, çalışılan kavramlarla ilgili olarak grupların denkliğini kontrol etmektir. Testten elde edilen sonuçlara parametrik test uygulayabilmek için test verilerinin normal dağılım göstermesi gerekmektedir (Mertler ve Vannatta, 2005).ABT ön-test sonuçlarının normallik 
dağılımı, her bir gruptaki (deney-kontrol) veri sayısı 30'dan büyük olduğundan Kolmogorov-Smirnov testi uygulanmıştır (Karaatlı, 2006). Bu analizden elde edilen sonuçlara göre, hem deney $(p=0,20>0,05)$ hem de kontrol $(p=0,17>0,05)$ grubunun verileri normal dağılım göstermektedir. Buradaki diğer bir varsayım varyansların homojenliğinin testidir. Yapılan Levene testi sonucunda grupların varyanslarının denk olduğu belirlenmiştir $(\mathrm{F}=0,918 ; \mathrm{p}=0,341)$. Bu analizlerden sonra, uygulanan bağımsız örneklemli $\mathrm{t}$ testinden elde edilen sonuçlar Tablo 5'te verilmiştir.

Tablo 5.ABT'nin Ön-test Uygulamasından Elde Edilen Veriler

\begin{tabular}{lcccccccc}
\hline & Gruplar & $\mathbf{N}$ & Ort. & Ss & Sh. & Sd & t & p \\
\hline Ön-test & Deney & 39 & 11,46 & 5,14 & .824 & 80 & 4,20 & .001 \\
ABT & Kontrol & 43 & 15,67 & 3,89 & .594 & & & \\
\hline
\end{tabular}

Tablo 5 incelendiğinde, deney grubunun ortalamasının 11,46 (5,14), kontrol grubunun15,67(3,89) olduğu görülmektedir. Ortalamalar arasındaki farkın anlamlılığına yönelik yapılan bağımsız örneklemli $t$ testi sonucunda aradaki ortalama farkın kontrol grubu lehinde anlamlı olduğu görülmektedir $(\mathrm{t}(80)=4.20, \mathrm{p}=0,001)$.

\section{ABT'nin Son-test Uygulamasindan Elde Edilen Bulgular}

Tablo 5'te görüldüğü gibi deney ve kontrol grubunun önbilgi düzeyleri denk değildir. Ancak işbirlikli öğrenme yönteminin akademik başarı üzerindeki etkisini belirleyebilmek için grupların başlangıç seviyelerinin (başarı testi sonuçları) birbirine denk olması ya da denkliği sağlayan analiz yöntemi kullanılması gerekir. Son- testlerin karşılaştırılmasında, grupların ön-test sonuçlarını birlikte değişen (covariate)olarak kontrol altına alabilen kovaryans (ANCOVA) analizi kullanılmıştır. Analiz öncesi son-test verilerinin normalliği incelenmiştir. Kolmogorov-Smirnov testi sonucu, hem deney $(p=0,20>0,05)$ hem de kontrol $(p=0,075>0,05)$ grubunun verilerinin normal dağılım gösterdiği tespit edilmiştir. ANCOVA için diğer bir varsayım hata varyanslarının eşit olmasıdır. Yapılan Levene testi sonucunda gruplar arasında denklik olduğu belirlenmiştir ( $\mathrm{F}(1 ; 79=0,001 ; \mathrm{p}=0,973)$.

Kovaryans analizinden elde edilen tanımlayıcı istatistikler Tablo 6' da, analiz sonuçları Tablo 7 'de verilmiştir.

Tablo 6.ABT'nin Son-test Uygulamasından Elde Edilen Tanımlayıcı İstatistikler

\begin{tabular}{llll}
\hline Grup & N & Ortalama & Düzeltilmiş ortalama \\
\hline Deney grubu & 39 & 16,91 & 17,96 \\
Kontrol Grubu & 43 & 17,77 & 16,80 \\
\hline
\end{tabular}

Tablo 6'dan görüldüğü gibi deney grubunun son-test ortalaması 16,91 iken kontrol grubunun $17,77^{\prime}$ tür. Verilere uygulanan kovaryans analizi sonucunda deney grubunun sontest düzeltilmiş/ayarlanmış ortalaması 17,96; kontrol grubunun ise 16,80 olarak hesaplanmıştır (Tablo 6). Bu şekilde öğrencilerin başlangıç başarı düzeylerindeki farklılığın akademik başarı üzerindeki etkisi ortadan kaldırılmış olmaktadır. 
Tablo 7.ABT’ninSon-test Verilerine Yönelik ANCOVA Analizi Sonuçları

\begin{tabular}{llllll}
\hline $\begin{array}{l}\text { Varyansın } \\
\text { kaynağ1 }\end{array}$ & $\begin{array}{l}\text { Kareler } \\
\text { toplami }\end{array}$ & Sd & $\begin{array}{l}\text { Kareler } \\
\text { ortalaması }\end{array}$ & F & $\begin{array}{l}\text { Anlamlılık } \\
\text { düzeyi (p) }\end{array}$ \\
\hline Öntest & 459,346 & 1 & 459,346 & 21,342 & 0,0001 \\
Grup & 21,452 & $\mathbf{1}$ & 21,452 & $\mathbf{1 , 0 4 3}$ & $\mathbf{0 , 3 1 0}$ \\
Hata & 1480,327 & 79 & 20,560 & & \\
\hline
\end{tabular}

Tablo 7'den görülebileceği gibi, işbirlikli öğrenme yönteminin uygulandığ 1 deney grubu ile geleneksel öğretim yaklaşımının uygulandığı kontrol grubunun düzeltilmiş son-test puan ortalamaları arasındaki fark anlamlı değildir $[\mathrm{F}(1,79)=1,043, \mathrm{p}>$.05]. Bir başka ifadeyle, işbirlikli öğrenme yöntemi, geleneksel yaklaşımla karşılaştırıldığında öğrencilerin Muhasebe Denetimi dersine yönelik akademik başarıları üzerinde anlamlı bir farklılaşma oluşturmamıştır.

Jigsaw Görüş Ölçeğinden Elde Edilen Veriler

Deney grubu öğrencilerine Şimşek (2007) tarafından geliştirilen Jigsaw Görüş Ölçeği uygulanmış ve Tablo 8'deki bulgular elde edilmiştir.

Tablo 8. Jigsaw Görüş Ölçeğinden Elde Edilen Verilerin Frekans ve Yüzde Dağılımları

\begin{tabular}{|c|c|c|c|c|c|c|c|c|c|c|}
\hline & 5 & & 4 & & 3 & & 2 & & 1 & \\
\hline & $\bar{f}$ & $\%$ & $\mathrm{f}$ & $\%$ & $f$ & $\%$ & $\mathrm{f}$ & $\%$ & & $\%$ \\
\hline $\begin{array}{l}\text { 1.Genel akademik başarı } \\
\text { üzerine }\end{array}$ & 15 & 35,7 & 17 & 40,5 & 9 & 21,4 & - & - & 1 & 2,4 \\
\hline $\begin{array}{l}\text { 2.Yüksek düzeyde düşünme } \\
\text { becerisini geliştirmede }\end{array}$ & 14 & 33,3 & 16 & 38,1 & 100 & 23,8 & 1 & 2,4 & 1 & 2,4 \\
\hline $\begin{array}{l}\text { 3.Çalışma konusuna karşı } \\
\text { ilgili olmada }\end{array}$ & 14 & 33,3 & 13 & 31,0 & 13 & 31,0 & 2 & 4,8 & - & - \\
\hline $\begin{array}{l}\text { 4.Derse devam sağlama } \\
\text { açısından }\end{array}$ & 24 & 57,1 & 10 & 23,58 & 6 & 14,3 & 1 & 2,4 & 1 & 2,4 \\
\hline $\begin{array}{l}\text { 5.Öğretmen ile iletişim } \\
\text { sıklığ1 ve kalitesi üzerine }\end{array}$ & 28 & 66,7 & 5 & 11,9 & 7 & 16,7 & 2 & 4,8 & - & - \\
\hline $\begin{array}{l}\text { 6.Derse verilen dikkat süresi } \\
\text { bakımından }\end{array}$ & 22 & 52,4 & 12 & 28,6 & 8 & 19,0 & - & - & - & - \\
\hline $\begin{array}{l}\text { 7.Çalışma konusundaki } \\
\text { bilgilerimi teşhis etme } \\
\text { yeteneğim üzerine }\end{array}$ & 15 & 35,7 & 14 & 33,3 & 11 & 26,2 & 2 & 4,8 & - & - \\
\hline $\begin{array}{l}\text { 8.Sınıf ve grup arkadaşlarım } \\
\text { ile iletişim sıklığı ve } \\
\text { kalitesine }\end{array}$ & 19 & 45,2 & 12 & 28,6 & 8 & 19,0 & 2 & 4,8 & 1 & 2,4 \\
\hline $\begin{array}{l}\text { 9.Bir kavramın tamamen } \\
\text { anlaşılması için gereken } \\
\text { zamanı sağlama açısından }\end{array}$ & 14 & 33,3 & 15 & 35,7 & 9 & 21,4 & 3 & 7,1 & 1 & 2,4 \\
\hline $\begin{array}{l}\text { 10.Genel sinıf atmosferinin } \\
\text { kalitesi bakımından }\end{array}$ & 9 & 21,4 & 21 & 50,0 & 8 & 19,0 & 3 & 7,1 & 1 & 2,4 \\
\hline $\begin{array}{l}\text { 11.Öğretmen ile demokratik } \\
\text { ve dostça ilişki kurabilme } \\
\text { üzerine }\end{array}$ & 23 & 54,8 & 12 & 28,6 & 4 & 9,5 & 1 & 2,4 & 2 & 4,8 \\
\hline $\begin{array}{l}\text { 12.Konuların derinlemesine } \\
\text { araştırılması bakımından }\end{array}$ & 16 & 38,1 & 19 & 45,2 & 4 & 9,5 & 2 & 4,8 & 1 & 2,4 \\
\hline
\end{tabular}


İşbirlikli Öğrenme Yönteminin Yüksekokul Öğrencilerinin Muhasebe Denetimi Konularını Anlamaları Üzerine Etkisi

\begin{tabular}{|c|c|c|c|c|c|c|c|c|c|c|}
\hline $\begin{array}{l}\text { 13.Derslerde kendini ifade } \\
\text { edebilme yeteneği üzerine }\end{array}$ & 20 & 47,6 & 15 & 35,7 & 7 & 16,7 & - & - & - & - \\
\hline $\begin{array}{l}\text { 14.Derse ön hazırlık } \\
\text { yapmayı sağlama acısından }\end{array}$ & 27 & 64,3 & 10 & 23,8 & 4 & 9,5 & - & - & 1 & 2,4 \\
\hline
\end{tabular}

Tablo 8, deney grubu öğrencilerinin kendilerine uygulanan Jigsaw tekniği ile ilgili görüşlerini göstermektedir. Öğrencilerin tekniğe bakış açılarının genel olarak olumlu olduğu frekans ve yüzde dağılımlarından görülmektedir. Teknik, özellikle "öğretmen ile iletişim sıklığ1 ve kalitesi üzerine" (\%66,7); "derse ön hazırlık yapmayı sağlama açısından" $(\% 64,3)$ ve "derse devamı sağlama açısından" (\%57,1) oldukça fazla etkilidir. Öğrencilerin genel olarak olumlu düşüncelerinin yanı sıra, olumsuz görüş beyan eden oldukça sınırlı sayıda öğrenci de bulunmaktadır. Ayrıca 15. madde olarak belirtilen "bu tekniğin uygulanması ile ilgili olumlu veya olumsuz görüşlerinizi yazınız" açık uçlu ifadesinde öğrencilerin yorumlarına göre; Jigsaw tekniği, öğrenciler açısından derslere ilginin artmasını sağlayan bir teknik olarak değerlendirilebilir.

Deney grubu öğrencilerinden bazılarının bu teknik hakkında 15.maddeye yazdıkları yorumlar Tablo 9' da gösterilmiştir.

Tablo 9. Deney Grubu Öğrencilerinin Jigsaw Tekniği Hakkındaki Düşünceleri

\begin{tabular}{|c|c|}
\hline Olumlu Görüş & Olumsuz Görüş \\
\hline $\begin{array}{l}\text {-Dersi anlama açısından ve sorumluluk alma } \\
\text { açısından iyi bir çalışmaydı. }\end{array}$ & $\begin{array}{l}\text {-Genel olarak süre yetersiz gibiydi ve grupta } \\
\text { ödevini yapmayanların olması olumsuz yönde } \\
\text { etkiliyordu. }\end{array}$ \\
\hline $\begin{array}{l}\text {-Derse olan ilgi ister istemez arttı. Derse } \\
\text { gelmeden ön hazırlı yapılması konusunda } \\
\text { başarılı oldu. }\end{array}$ & $\begin{array}{l}\text {-Grup üyelerinin hepsinin ders çalışmaması, } \\
\text { grubun düzenini bozması. }\end{array}$ \\
\hline $\begin{array}{l}\text {-Bazen arkadaşlarımızın anlattığını daha iyi } \\
\text { anlamamız sınıf içerisinde grup olduğu için } \\
\text { birbirimizle kaynaşmamız tanımamız gayet iyi. }\end{array}$ & $\begin{array}{l}\text {-Grup içerisinde benim verdiğim hassasiyeti grup } \\
\text { arkadaşımın vermemesi. }\end{array}$ \\
\hline $\begin{array}{l}\text {-Bana göre uzman kişilerle yapılan gruplandırma } \\
\text { daha olumludur. Çünkü } 10 \text { kişi aynı konuyu } \\
\text { okuduğu için konuyu sadece dinlemek bile } \\
\text { yeterli oluyor. }\end{array}$ & $\begin{array}{l}\text {-Bence, 5'er kişilik olan gruplar herkes farklı konu } \\
\text { anlattığı için bir derste anlamak biraz zor oluyor. } \\
\text { Sadece olumsuz olarak gördüğ̈üm kısım budur. }\end{array}$ \\
\hline $\begin{array}{l}\text {-Derse önceden hazırlık yapılması ve derste aktif } \\
\text { olunması, bilgi alışverişi yapılması. En son }\end{array}$ & $\begin{array}{l}\text {-Derse devamsızlık olduğunda konuların telafi } \\
\text { edilmemesi. }\end{array}$ \\
\hline
\end{tabular}

Deney grubu öğrencilerinin görüş ölçeğine verdikleri cevaplar genel olarak değerlendirildiğinde, Jigsaw tekniği, öğrencilerin derslere hazırlıklı gelmelerini sağlaması açısından etkili bir teknik olurken; grup üyelerinin eşit özveriyle konularına hazırlanmamaları öğrencilerde olumsuzluk yaratmaktadır. Ayrıca, teknik, grup üyelerinin birbirleriyle kaynaşmalarını sağlaması açısından etkili olarak değerlendirilmiştir. Öğrenciler, ana grup üyelerinin birbirlerine konuları anlatmak için gerekli olan ders saati süresinin yetersiz olduğunu bildirmişlerdir. Genel olarak yorumlar ele alındığında ise, tekniğin ciddiyetle uygulanması halinde verimli ve etkin bir yöntem olduğu sonucuna ulaşılmıştır.

\section{Tartışma, Sonuç ve Öneriler}


$\mathrm{Bu}$ çalışma, muhasebe denetimi dersi alan öğrencilerin akademik başarıları üzerinde işbirlikli öğrenme yönteminin etki yaratıp yaratmadığını tespit etmek üzere hazırlanmıştır. $\mathrm{Bu}$ amaca ulaşmak için bir deney ve bir kontrol grubundan oluşan yarı-deneysel tasarım kullanılmıştır. Kontrol grubuna öğretmenin aktif olduğu öğrencilerin pasif dinleyici konumunda olduğu geleneksel yaklaşım uygulanırken deney grubuna öğrencilerin aktif öğretmenin rehber konumunda olduğu işbirlikli öğrenme yaklaşımı uygulanmıştır. Uygulamanın denkliğini sağlamak için her iki sınıftaki uygulamalar aynı öğretim üyesi tarafından yürütülmüştür. Uygulama öncesinde uygulanan test sonucunda, çalışılan kavramlarla ilgili kontrol grubu öğrencilerinin önbilgi düzeylerinin $(\bar{X}=15,67)$ deney grubu $(\bar{X}=11,46)$ ile karşılaştırıldığında daha yüksek olduğu belirlenmiştir. İki grup arasındaki 4,21'lik ortalama fark, yapilan $\mathrm{t}$ testi sonucunda istatistiksel olarak da anlamlı bulunmuştur $(\mathrm{t}(80)=4.20, \mathrm{p}=0,001)$. Bu farkın oluşmasındaki temel etkenin kontrol grubu öğrencilerinin çoğunluğunun meslek lisesi kökenli olmasından kaynaklandığ düşünülmektedir. İki grup arasında manidar farklılık olması nedeniyle son-testlerin karşılaştırılması ANCOVA (Kovaryans analizi) ile gerçekleştirilmiştir. Uygulama sonrasında kontrol $(\bar{X}=17,77)$ ve deney $(\bar{X}=16,91)$ grubunun son-test puanları karşılaştırıldığında, yine kontrol grubunun daha başarılı olduğu görülmektedir. Bu değişim Grafik 1 de daha net görülmektedir.

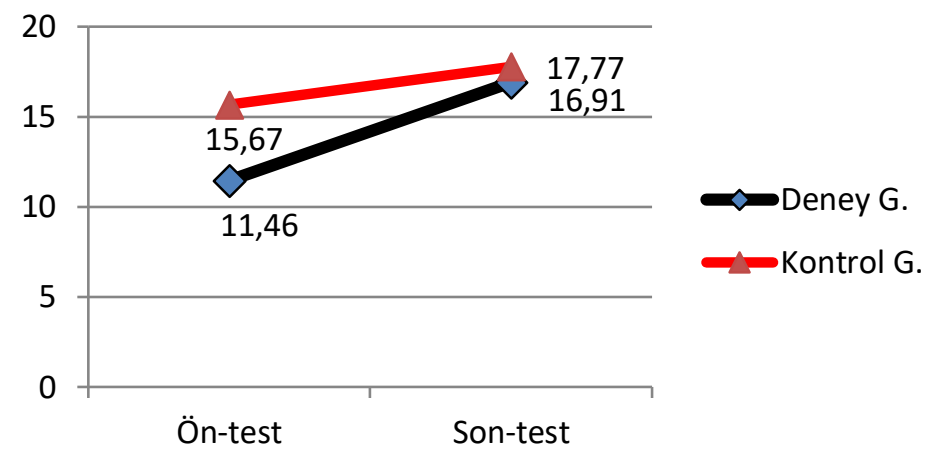

Grafik 1. Deney ve kontrol grubunun ön ve son-test ortalamaları

Grafik 1 den görüldüğü gibi, ön-testten son-teste kontrol grubu (17,77-15,67) 2,10 puanlık bir artış sağlarken deney grubu $(16,91-11,46)$ 5,45 puanlık bir artış sağlamıştır. Deney grubundaki değişim daha fazla olmuştur. Uygulamanın etkisini istatistiksel olarak ortaya çıkarmak için yürütülen ANCOVA analizi sonucunda öncelikle düzeltilmiş son-test ortalamaları deney grubu için 17,96 ve kontrol grubu için 16,80 olarak belirlenmiştir. Buradan anlaşılacağı gibi deney grubunun son-test ortalaması daha yüksek olmakla birlikte kontrol grubu ile aralarında 0,59 puanlık bir fark oluşmuştur. Tablo 7' deki ANCOVA sonucu incelediğinde deney ve kontrol grubu arasında oluşan ortalama farkın anlamlı olmadığı anlaşılmaktadır[F(1,79)=0,27, p>.05]. Buradan işbirlikli öğrenme yönteminin meslek yüksekokulu öğrencilerinin muhasebe denetimi dersine yönelik akademik başarıları üzerinde geleneksel yaklaşıma göre bir artış sağladığı ancak bu artışın istatistiksel olarak anlamlı olmadığı söylenebilir. Bu çalışmanın sonucunu destekler şekilde, Kunkel ve Shafer (1997), Riley ve Ward (2017), Gabbin ve Wood (2008), Lancaster ve Strand (2001) tarafından muhasebe alan dersleri üzerine yapılan çalışmalarda da işbirlikli öğrenme yönteminin öğrencilerin akademik performansları üzerinde etkili olmadığı sonucuna varılmıştır. Bu çalışmada öğrenci sayısı fazla olduğu için deney grubu öğrencileri 6 kişilik gruplarda 
çalışmışlardır. Bu durum öğrencilerin verimli çalışmasını olumsuz etkilemiş olabilir. Genellikle işbirlikli öğrenme gruplarının 2-6 öğrenci arasında olması önerilmekle birlikte, sayı ne kadar az olursa verimin de o oranda artacağı vurgulanmaktadır (Sharan, 1989; Slavin, 1988). Ancak bunun aksini ortaya koyan çalışmalar da mevcuttur. Aydın ve Er (2011), Genel Muhasebe dersine yönelik İ̈BF öğrencileri ile yürüttükleri bir dönemlik (4 ay) deneysel çalışmada işbirlikli öğrenme yöntemi ile geleneksel yaklaşımı karşılaştırmışlardır. Çalışma sonucunda öğrencilerin Genel Muhasebe dersindeki kavramlara yönelik akademik başarıları üzerinde işbirlikli öğrenme yönteminin geleneksel yönteme göre daha etkili olduğunu belirlemişlerdir. Gerek çalıştıkları öğrencilerin fakülte öğrencileri olması gerekse uygulamanın 4 ay sürmesi açısından şu anki çalışmadan farklılaşmaktadır. Sürenin uzun olmasının öğrencilerin yönteme alışmasında önemli bir avantaj olduğu düşünülmektedir. Ayrıca yüksekokul öğrencilerinin öğrenme sorumluluğu, fakülte öğrencilerinden önemli oranda farklılık göstermektedir. Aydın ve Er'in (2011) çalışmalarının sonucunu destekler şekilde alan yazında yapılan bir çalışmada, işbirliğine dayalı öğrenme yöntemine dayalı öğretilen öğrencilerin uygulama ve analiz seviyesindeki muhasebe bilgilerini daha iyi öğrendikleri iddia edilmektedir (Hwang, Lui ve Tong 2008).Daha önce belirtildiği gibi Caldwell ve arkadaşları (1996) yaptıkları çalışmada işbirlikli öğrenme yönteminin "Muhasebe İlkeleri I" dersi için etkili olduğunu, fakat "Muhasebe İlkeleri II" dersi için etkisinin bulunmadığını belirlemişlerdir.

Geleneksel sınıf ile karşılaştırıldı̆̆ında işbirlikli öğrenme ortamının, akademik başarı yanında bilimsel süreç becerileri (Bozdoğan, Taşdemir ve Demirbaş, 2006), bireysel sorumluluk duygusu (Şengören ve Kavcar, 2009), öğrenilen bilginin kalıcılığ1 ve derse karşı tutum (Tezcan, Yilmaz ve Babaoğlu, 2005), birlikte çalışma becerisi ve sosyalleşme (Saban, 2004) ve öğrencilerin birbirlerine olan güvenleri (She, 1999) gibi birçok diğer becerinin gelişimine katkı sağladığ 1 literatürde belirtilmektedir. Cottell ve Millis (1992) ile Hwang ve arkadaşları (2005) tarafından yapılan çalışmalarda işbirlikli öğrenme yöntemi ile öğrencilerin akademik performansları ve muhasebe algıları arasında olumlu bir ilişki tespit edilmiştir. Bu çalışmada sadece akademik başarıya konsantre olunduğu için diğer becerilerdeki gelişimin izlenmesi çalışmanın kapsamı dışında tutulmuştur. Bununla birlikte Jigsaw tekniği görüş anketi ile elde edilen verilerden, işbirlikli öğrenme yönteminin katkı sağladığ1 düşünülen diğer beceriler hakkında sınırlı bir tartışma yapılabilir. Özellikle anketin açık uçlu sorusuna verilen cevaplar değerlendirildiğinde, öğrencilerin grup üyelerinin özveriyle konularına hazırlanmaları, grup üyelerinin birbirleriyle kaynaşmaları, dersi daha iyi anlamaları, derse olan ilgilerinde artış ve öğrenme sorumluluğu alma gibi konulara vurgu yaptıkları görülmektedir. Anketin diğer maddelerine verilen cevaplar da işbirlikli öğrenme yönteminin birçok beceriyi desteklediği ve geliştirdiğinin bir göstergesidir. Buradan anlaşılacağı gibi işbirlikli öğrenme yöntemini sadece akademik başarı açısından değerlendirmek doğru değildir.

$\mathrm{Bu}$ çalışmada, işbirlikli öğrenme yönteminin akademik başarıyı olumlu yönde etkilememesine neden olduğu düşünülen birkaç faktör öğrencilerin verdiği cevaplar ile de desteklenmiştir. Araştırma kapsamında yer alan öğrenciler son sınıf öğrencileri olup iki senelik ön lisans eğitimleri süresince geleneksel yönteme göre dersleri almışlardır. İşbirlikli öğrenme yöntemi, öğrencinin aktif olarak derse hazırlanmasını ve katılımını sağladığından öğrencinin alışık olmadığı bir düzene adapte olmasını ve kabullenmesini gerektirmektedir.5 hafta süren araştırmanın ilk üç haftasında öğrenciler bu yöntemle öğrenmeye karşı direnmişler ve isteksiz bir şekilde uygulamaya katılmışlardır. Dolayısıyla yöntemi 
benimseyerek yöntemin kendilerine sağlayacağı faydayı görmeleri konusunda geç kalmışlardır. Diğer bir faktör, grup üyelerinin konularına hazırlanırken görevlerini ne kadar ciddiye aldıklarıyla ilgilidir. Konularına hazırlanırken, gereken titizlik ve özeni gösteren grup üyeleri, diğer grup üyelerinin herhangi birinin konularını özveriyle hazırlamamış olmalarından rahatsızlık duymuş ve bu uygulamanın kendileri için yararlı olmayacağ fikrine kapılmıştır. Çünkü yöntem, grubun tüm fertlerinin aynı özveri, titizlik ve özen ile konularına hazırlanmalarını gerektirmektedir. Üçüncü faktör, grup üyelerinin derslere devam etmelerinde yaşanan sorundur. Grup çalışması, derslere devamı zorunlu kıldığından öğrenci üzerinde baskı oluşturmakta ve yöntemin kendilerine sağlayacağı faydayı görmelerini engellemektedir. Ayrıca, derslere düzensiz devam edilmesi halinde eksikliklerin telafisi zor olmakta bu durum da tekniğin sağlayacağı faydayı azaltmaktadır.

İşbirlikli öğrenme yönteminin akademik başarı üzerinde olumlu etki yaratabilmesi için, öğrencilerin bu yöntemi uygulamayı kabullenmiş ve benimsemiş olmaları gerekir. Bu da yöntemin sadece muhasebe derslerinde değil ön lisans eğitimleri süresince yöntemin uygulanabileceği tüm dersler için uygulamanın yapılmasıyla mümkün olabilir. Öğrencinin sınıf içerisinde pasif olmasından ziyade aktif katılımının sağlanması başarı üzerinde önemli etki yaratacaktır. Bu çalışma, araştırmanın uygulama süresinin uzatılması, ana grup sayısının azaltılması ve aynı dönem içerisindeki farklı birkaç muhasebe dersinde aynı yöntemin uygulanmasıyla öğrencide alışkanlık yaratılması sağlanarak tekrarlanabilir. Böylece teoriye dayalı muhasebe dersleri ile kayıt esasına dayalı muhasebe dersleri üzerinde işbirlikli öğrenme yönteminin etkisi kıyaslanabilir.

\section{Kaynakça}

Anderson, W.L., Mitchell, S.M., \& Osgood, M.P. (2005). Comparison of Student Performance in Cooperative Learning and Traditional Lecture-based Biochemistry Classes, BiochemistryandMolecularBiologyEducation, 33(6), 387-393.

Aydın, S. ve Er, H. (2011). İşbirliğine Dayalı Öğrenme Yönteminin Genel Muhasebe Derslerindeki Etkinliği, World of Accounting Science, 13(2), 19-38

Bozdoğan, A.E., Taşdemir, A. ve Demirbaş, M. (2006). Fen Bilgisi Öğretiminde İşbirlikli Öğrenme Yönteminin Öğrencilerin Bilimsel Süreç Becerilerini Geliştirmeye Yönelik Etkisi, İnönü Üniversitesi Eğitim Fakültesi Dergisi, 11(7), 23-36.

Büyüköztürk, Ş. (2004). Sosyal Bilimler İçin Veri Analizi El Kitabı (4.baskı). Pegem Yayıncılık: Ankara.

Caldwell, M.B., Weishar, J. \& Glezen, G.W. (1996). The Effect of Cooperative Learning On Student Perceptions of Accounting in the Principles Courses, Journal of Accounting Education, 14(1), 17-36

Cooper, J. \& Mueck, R. (1990). StudentInvolvement in Learning: Cooperative Learning and College Instruction, Journal on Excellence in CollegeTeaching, 1, 68-76.

Cottell, P.G. \& Millis, J. B. (1992). Cooperative Learning in Accounting, Journal of Accounting Education, 10(1), 95-111.

Demir, B. (2015). Meslek Yüksekokullarında Verilen Muhasebe Eğitiminde Stajın Önemi, Sorunlar ve Çözüm Önerileri, Eğitim ve Öğretim Araştırmaları Dergisi, 4(3), 76-80 
Demircioğlu, H., Vural, S. ve Demircioğlu, G. (2012). REACT Stratejisine Uygun Hazırlanan Materyalin Üstün Yetenekli Öğrencilerin Başarısı Üzerinde Etkisi, Ondokuz Mayıs Üniversitesi Ĕ̆itim Fakültesi Dergisi, 31(2), 101-144.

Erol, M. (2004). Meslek Yüksekokullarında Muhasebe Eğitimi Alan Öğrencilerin Staj Uygulamasında Karşılaştıkları Sorunlar ve Çözüm Önerileri, Muhasebe ve Finansman Dergisi, 21, 136-142.

Gabbin, A. L. \& Wood, L. (2008). An ExperimentalStudy of Accounting Majors' AcademicAchievement Using Cooperative Learning Groups, Issues in Accounting Education, 23(3), 391-404

Genç, M. (2007). İşbirlikli Öğrenmenin Problem Çözmeye ve Başarıya Etkisi. (Yayınlanmamış Doktora Tezi). Marmara Üniversitesi/Eğitim Bilimleri Enstitüsü, İstanbul.

Hwang, N.R., Lui, G. \& Tong, M.Y. (2005). An Empirical Test of Cooperative Learning in a Passive Learning Environment, Issues in Accounting Education, 20(2), 151-165. https://doi.org/10.2308/iace.2005.20.2.151

Hwang, N.R., Lui, G. \& Tong, M.Y. (2008). Cooperative Learning in a Passive Learning Environment: a Replication and Extension, Issues in Accounting Education, 23(1), 67-75.

İstemil, A. (2011). 9. Sınıf Coğrafya Dersinde Kubaşık Öğrenme Yönteminin Öğrenci Akademik Başarısına Etkisi(Yayınlanmamış Yüksek Lisans Tezi). Marmara Üniversitesi/Eğitim Bilimleri Enstitüsü, İstanbul.

Judd, C.M., Smith, E.R. \& Kidder, L.H. (1991). Research Methods In Social Relations(6.Bask1). San Francisco: Holt, Rinehartand Winston, Inc.

Karaatlı, M. (2006). Verilerin Düzenlenmesi ve Gösterimi. Şeref Kalaycı (Ed.), SPSS Uygulamalı Çok Değişkenli İstatistik Teknikleri içinde (s.3-42). Ankara: Asil Yayıncılık.

Karacan, S. ve Karacan, E. (2004). Meslek Yüksekokullarında (MYO) Yapılan Staj Uygulamalarına İlişkin Bir Araştırma: Kalite ve Verimlilik İçin İş Yerleri-MYO İşbirliğinin Gereği, Kocaeli Üniversitesi Sosyal Bilimler Enstitüsü Dergisi, (8) 2, 168-184.

Kartal, Ş. ve Özbek, R. (2017). İşbirlikli Öğrenme Yönteminin Öğrencilerin İngilizce Dersine Yönelik Tutumlarına ve Başarılarına Etkileri, Abant İzzet Baysal Üniversitesi Eğitim Fakültesi Dergisi, 17 (2), 796-820.

Kunkel, J.G. \& Shafer, W.E. (1997). Effects of Student Team Learning in Undergraduate Auditing Courses, Journal of Educationfor Business, 72(4), 197-200, Advance online publication. doi: 10.1080/08832323.1997.10116853

Lancaster, K.A.S. \& Strand, C.A. (2001). Using the Team-Learning Model in a Managerial Accounting Class: An Experiment in Cooperative Learning, Issues in Accounting Education, 16(4), 549-567. https://doi.org/10.2308/iace.2001.16.4.549

Mertler, C.A., \& Vannatta, R.A. (2005). Advanced And Multivariate Statistical Methods: Practical Application And Interpretation (3.Baskı). United States: Pyrczak Publishing.

Meslek Lisesi Staj Yönetmeliği, https://www.stajyerim.com/staj-bilgileri/meslek-lisesi-stajyonetmeligi/ (erişim tarihi: 21.04.2019). 
Mesleki ve Teknik Eğitim Bölgesi İçindeki Meslek Yüksekokulu Öğrencilerinin İşyerlerindeki Eğitim, Uygulama ve Stajlarına İlişkin Esas ve Usuller Hakkında Yönetmelik. (2002). T.C. Resmî Gazete, 24762, 22 Mayıs 2002.

Nichols, J., \& Miller, R. (1994). Cooperative Learning and Student Motivation, Contemporary Educational Psychology, 19(2), 167-178.

Özkıdık, K. (2010). İlköğretim 7. Sınıf Fen Ve Teknoloji Dersi Yaşamımızdaki Elektrik Ünitesinin Öğretiminde İşbirlikli Öğrenme Yönteminin Öğrenci Başarısına Ve Tutuma Etkisi,(Yayınlanmamış Yüksek Lisans Tezi). Gazi Üniversitesi/ Eğitim Bilimleri Enstitüsü, Ankara.

Özsarı, T. (2009). İlköğretim 4. sinıf öğrencileri üzerinde işbirlikli öğrenmenin matematik başarısı üzerine etkisi: Probleme dayalı ögrenme (PDÖ) ve öğrenci takımlar başarı bölümleri (ÖTBB). (Yayınlanmamış Yüksek Lisans Tezi). Ege Üniversitesi/Sosyal Bilimler Enstitüsü, İzmir.

Riley, J. \& Ward, K. (2017), Active Learning, Cooperative Active Learning, and Passive Learning Methods in an Accounting Information Systems Course, Issues in Accounting Education, 32(2), 1-16. Advance online publication. https://doi.org/10.2308/iace-51366

Robson, C. (1998), Real World Research. Oxford, UK: Blackwell Publishers Ltd.

Saban, A. (2004). Öğrenme Öğretme Süreci Yeni Teori Ve Yaklaşımlar. Ankara: Nobel Yayın.

Sharan, Y. \& Sharan, S. (1989). Group Investigation Expands Cooperative Learning, Educational Leadarship, 47(4), 17-21.

She, H-C. (1999). Students' Knowledge Construction in Small Groups in the Seventh Grade Biology Labaratory; Verbal Communication and Phsical Engagement, Int. J.Sci.Educ.,21(10),1051- 1066.

Slavin, R. E., (1980). Cooperative Learning, Review of Education Research, 50(2), 315-342.

Slavin, R.E. (1988). Small Group Methods, The International Encyclopedia Of Teaching And Teacher Education, Oxford: Pergamonpres

Slavin, R.E. (1990). Cooperative Learning: Theory, Research And Practice. New Jersey: Prentice Hall.

Slavin, R.E. (2008). Cooperative Learning, Successfor All, and Evidence-based Reform in Education, Éducation et didactique,2(2), 150-159.

Şengören, S.K. \& Kavcar, N. (2009). İşbirlikliÖğrenmenin Fizik Öğretmen Adaylarının Duyuşsal Ürünleri Üzerine Etkisi, E-Journal of New World Sciences Academy, 4(2), 357-371.

Şimşek, Ü. (2007). Çözeltiler ve Kimyasal Denge Konularında Uygulanan Jigsaw ve Birlikte Öğrenme Tekniklerinin Öğrencilerin Maddenin Tanecikli Yapıda Öğrenmeleri ve Akademik Başarıları Üzerine Etkisi. (Yayımlanmamış Doktora tezi). Atatürk Üniversitesi/Fen Bilimleri Enstitüsü, Erzurum.

Tezcan, H., Yılmaz, Ü., ve Babaoğlu, M. (2005). Radyoaktivite Öğretiminde İşbirlikli Öğrenme Yöntemi İle Geleneksel Öğretim Yönteminin Başarıya Etkileri, Pamukkale Üniversitesi Eğitim Fakültesi Dergisi, 17,55-67. 
Yelboğa, A. (2008). Güvenirliğin Değerlendirilmesinde Genellenebilirlik Kuramının Kullanılması: Endüstri Ve Örgüt Psikolojisinde Bir Uygulama, Psikoloji Çalışmaları Dergisi, 28(0), 35-54.

Yıldırım, Z. (2011). Kubaşık Öğrenme Yönteminin Küme Destekli Bireyselleştirme Tekniğinin 6. Sını Öğgrencilerinin Matematik Dersindeki Başarılarına Ve Tutumlarına Etkisi, (Yayınlanmamış Yüksek Lisans Tezi). Atatürk Üniversitesi/Eğitim Bilimleri Enstitüsü, Erzurum. 